\title{
Estimation of Exserohilum turcicum Efficiency in Quality \\ Protein Maize Crosses: Component of Resistance
}

\author{
Saket Kumar ${ }^{1 *}$, Rajeev Pratap Singh ${ }^{\mathbf{1}}$ and Rajesh Singh ${ }^{2}$ \\ ${ }^{1}$ Department Environment Science and Technology, IESD, BHU, Varanasi, India \\ ${ }^{2}$ Department of Genetics and Plant Breeding, Institute of Agricultural Sciences, $B H U$, \\ Varanasi, India \\ *Corresponding Author: Saket Kumar, Department Environment Science and \\ Technology, IESD, BHU, Varanasi, India.
}

Received: February 20, 2020

Published: April 29, 2020

(C) All rights are reserved by Saket Kumar., et al.

\begin{abstract}
NCLB is a seasonal maize crop disease which affected maize leaf under humid environment but in some cases QPM hybrid showed resistance to this disease. Author was selected 5 QPM and 6 non QPM inbred line from the screening and developed 30 crosses of QPM hybrid. These crosses were showing in two different environments (Irrigated and Rain-fed) along with two checks (Malviya Makka Hybrid 2 and local hybrid). After days to 50\% tasseling NCLB observation was performed. QPM hybrid crosses showed better growth and development but checks infected to NCLB at $50 \%$ tasseling and silking which provide less amount of food supplements due to losses major amount of chlorophyll content.
\end{abstract}

Keywords: E. turcicum; Environments; NCLB; QPM; Yield

\section{Abbreviations}

NCLB: Northern Corn Leaf Blight; QPM: Quality Protein Maize; ANOVA: Analysis of Variance; WMD: Weighted Mean Disease Rating; AUDPC: Area Under Disease Progress Curve; BHU: Banaras Hindu University; RGSC: Rajeev Gandhi South Campus; E: Environment; PSI: Percentage Severity Index.

\section{Introduction}

Maize (Zea mays) is a biannual crop belonging to the family of grasses (Poaceae). It is grown $58^{\circ} \mathrm{N}$ to $40^{\circ} \mathrm{S}$, from below sea level to higher than $3000 \mathrm{~m}$ areas that cover $250 \mathrm{~mm}$ to $5000 \mathrm{~mm}$ rainfall in per year with a growing cycle about 3 months [1]. The most suitable temperature for maize germination is $21^{\circ} \mathrm{C}$ but growing $32^{\circ} \mathrm{C}$, minimum temperature is $7^{\circ} \mathrm{C}$ suitable for maize germination in cool environment. India contributes $2 \%$ of world production and $5 \%$ corn acreage [2], such types maize can be grown under diverse climatic conditions. Northern India is better for Kharif (Rainy) season maize crops. QPM (Quality Protein Maize) hybrid increase body growth weight of poultry and pigs [3], so it mostly used for grain yield studies (Mbuya., et al. 2011) and ability in different environments [4]. QPM is a substitution protein which is used in animal feed composites and reducing its cost [5]. It significantly improves the nutritional status who cannot afford proteinrich foods to supplement their diet. The QPM utility is animal feed in the parts of the world which used in high ratio of meat supply. Ghana's children are feed normal maize as porridge with containing high lysine and tryptophan reduced stunting and better growth capabilities [6].

Exserohilum turcicum is a foliar disease-causing yield loss reaching up to $100 \%$ on susceptible maize varieties in India [7], it is called NCLB (Northern corn leaf blight) disease [8]. It is a prev- alent disease of India, typically develop first on lower leaves and spreads in the middle and upper thirds portion [1] of the canopy, as illustrated to a rating scale (Elliott and Jenkins 1946). The rate of photosynthesis is reduction about $91 \%$ when severity of TLB exceeded 50\% in maize crops [9]. Higher and cooler areas are more favorable for NCLB diseases development in different environment [10]. Maize hybrid damaging is caused during time of infection under favorable humid environmental condition where temperature ranging 18 to $27^{\circ} \mathrm{C}$ on the severity of crop stage development. Therefore TLB is more significant for economic damage to severe incidence before flowering and causes great damage of maize crops [11]. The objective of this study was to determine "Estimation of Exserohilum turcicum efficiency in Quality Protein Maize Crosses: component of resistance" from the collected maize crop data under natural condition.

\section{Materials and Methods}

Experimental design and data collection

In this experiment 5 QPM and 6 non QPM inbred from the initial screening [11], design 30 crosses and grow in two environments (1. Agricultural Farm BHU, Varanasi and, 2. RGSC, Barkachha, Mirzapur) along with two check (Malviya makka 2 hybrid and a local hybrid) in a border row. These crosses (CML-141X HUZM 185, CML-141X V336, CML-141X V351, CML-141X CML-141, CML-141X V335, CML-141X HUZM 478, CML-176 X HUZM 185, CML-176 X V336, CML-176 X V351, CML-176 X CML-141, CML-176 X V335, CML-176 X HUZM 478, CML-193X HUZM 185, CML-193X V336, CML-193X V351, CML-193X CML-141, CML-193X V335, CML-193X HUZM 478, DMR-QPMX HUZM 185, DMR-QPMX V336, DMR-QPMX V351, DMR-QPMX CML-141, DMR-QPMX V335, DMR-QPMX HUZM 478, HKI-164-7-6X HUZM 185, HKI-164-7-6X V336, HKI-164-7-6X V351, HKI-164-7-6X CML-141, HKI-164-7-6X V335, HKI-164-7-6X 
HUZM 478) were sowed in two replications. After 50\% flowering, single cross formation was performed during Rabi (winter) season 2015-16 and Kharif (summer) season 2016. The Agricultural Farm BHU (E1) was irrigated and RGSC Barkachha (E2), Mirzapur was rain-fed environments during Rabi (winter) season 2015-16 and Kharif (Rainy) season 2016. The fertilizer rates were $150 \mathrm{~kg} / \mathrm{ha}$ DAP at planting and application of $200 \mathrm{~kg} / \mathrm{ha}$ of Urea in 3 splits that is $1 / 3$ after 21 days of germination, $1 / 3$ at knee height and last doses during flowering and irrigation time to time but second environment was control for irrigation [12]. Both environments temperature was differ in soil and moisture condition in which first environment has high moisture and alluvial soil and second environment has low moisture, red soil and cloudy condition.

\begin{tabular}{|c|c|c|c|}
\hline Sr. No. & QPM Inbreds & Pedigree and Sources & Characteristic Features \\
\hline 1 & CML-141 & Pop, CIMMYT & White flint Kernel, dwarf height, medium to late duration \\
\hline 2 & CML-176 & $\begin{array}{l}\mathrm{P}-63-12-2-1 / \mathrm{P} 67-5-1-1)-1-2-\mathrm{B}-\mathrm{B}, \\
\text { CIMMYT }\end{array}$ & White kernel medium to late duration \\
\hline 3 & CML-193 & CY0162-B-1-1-B (S-Afrika), CIMMYT & Medium height, medium to Late duration \\
\hline 4 & DMR-QPM-58 & Shakti 1 DMR & Orange yellow flint kernel, Early duration Tall height \\
\hline \multirow[t]{2}{*}{5} & HKI-164-7-6 & CML 164, Kernel & Yellow, semi dent, medium to late height and duration \\
\hline & Non QPM Inbreds & Pedigree and Sources & Characteristic Features \\
\hline 6 & HUZM-185 & Seed tec-1250-1-2-2-1-\#\#, BHU, Varanasi & $\begin{array}{l}\text { White flint kernel, medium duration, tall height and good grain } \\
\text { yield }\end{array}$ \\
\hline 7 & V-336 & $\begin{array}{l}\text { CML-145, P-63CDHC 181-3-2-1-4\#2- } \\
\text { BBBB\#, VPKAS Almora }\end{array}$ & $\begin{array}{l}\text { Yellow, Flint Kernel, medium duration, leaf and tassel angle is } \\
\text { small, straight leaf attitude. }\end{array}$ \\
\hline 8 & V-351 & Shakti (So) He 25, VPKAS, Almora & Orange yellow, flint kernel, early duration better yield \\
\hline 9 & CM-141 & Pool33(Alm), VPKAS, Almora & Yellow kernel medium to late duration, curved tassel \\
\hline 10 & V-335 & TZI-25, VPKAS, Almora & Orange, flint kernel, short to medium duration \\
\hline 11 & HUZM-478 & BH3427, BHU, Varanasi & $\begin{array}{l}\text { Yellow flint kernel, late duration, small wide leaf angle, } \\
\text { anthocynin present }\end{array}$ \\
\hline
\end{tabular}

Table 1: Characteristic features of selected QPM and non QPM inbred in Rabi (winter) season 2015-16 and Kharif (Rainy) season 2016 (Saket., et al. 2017).

After 50\% flowering NCLB data was recorded of QPM crosses which was naturally developed in both environments. NCLB severity was recorded using a 1 to 5 scale, in which 1 indicated highly resistant and 5 highly susceptible reactions. Data analysis was performed with converted data into percentage severity index [13] using by following formula:

PSI (\% Severity Index $)=$ Numerical rating/Total number of plants observed x Maximum rating

\section{Statistical analysis}

AUDPC (area disease under disease progress curve) analysis of variance (ANOVA) was performed for two years data using SAS software (version 6.03; SAS Institute Inc., Cary, NC 1997). Individual environment was rated through weighted mean disease rating (WMD) values for each replication. WMD (Weighted Mean Disease) is providing equivalent data to an area disease under disease progress curve (AUDPC). The divided values were summed over all intervals and divided in number of development days which called as, "Standardized UDPC" rating in publication order [14], line was represented in only one replication within per environment. Least mean square mean was calculated using the procedure of SAS (SAS Institute, Cary, NC) to obtain average rating over the two replications for each line in per environments. Data of QPM crosses yield and yield related traits analysis along with PSI (Percentage Severity Index) of NCLB were analyzed using by SAS statistical package (SAS 2002). This was followed by significance tests in each cross using analysis of variance (ANOVA) with entry in both locations within two replications as random factors.

\section{Heritability (h2)}

Heritability was estimated from the analysis of variance with the help of following formula (Nyquist; 1991).

H2=1- [MS (Genotype x Environments)]/MS(Genotype)

\section{Results and Discussion}

Growth rate of NCLB disease was recorded as resistance to $E$. turcicum in E1 during field condition in Rabi season 2015-16. The absence of significance correlation between days to heading and disease severity, indicate significance correlation $(\mathrm{P}<0.001)$ among the disease severity and AUDPC correlated E2 environments. The AUDPC was used more appropriate in effect of E. turcicum analysis due to high correlation between disease severity in E2 [15] Thirty QPM hybrids crosses positive contribution in both environments interaction but these crosses were more severity in E2 environments than E1. Different trait of QPM crosses did not show any variation in the analysis. The AUDPC values revealed genotype variation in year to year interaction of QPM crosses. Such types QPM genotypes were highly significant, the reproducibility condition of E. turcicum was observed with scoring method. Correlation coefficient values of AUDPC showed non-significant in E1 experiments and days to heading. 


\begin{tabular}{|l|c|c|c|c|c|c|c|c|c|c|}
\hline \multirow{2}{*}{$\begin{array}{l}\text { Source of } \\
\text { variation }\end{array}$} & \multicolumn{9}{|c|}{ Mean sum of square } \\
\cline { 2 - 11 } & & $\begin{array}{c}\text { days to 50 } \\
\text { \% Tasseling }\end{array}$ & $\begin{array}{c}\text { Days to } \\
\mathbf{5 0 \%} \text { Silking }\end{array}$ & $\begin{array}{c}\text { Days to 75\% } \\
\text { Brown Husk }\end{array}$ & $\begin{array}{c}\text { Plant } \\
\text { Height (cm) }\end{array}$ & $\begin{array}{c}\text { Ear Height } \\
\text { (cm) }\end{array}$ & $\begin{array}{c}\text { Cob } \\
\text { Length } \\
\text { (cm) }\end{array}$ & $\begin{array}{c}\text { 100 Seed } \\
\text { Weight }\end{array}$ & $\begin{array}{c}\text { Grain Yield } \\
\text { Per Plant (g) }\end{array}$ & AUDPC \\
\hline Replications & 2 & 4.229 & 2.316 & 1.257 & 0.215 & 0.310 & 0.258 & 0.351 & 0.205 & 9196.523 \\
\hline Treatment & 30 & $39.7248^{* *}$ & $49.6397 * *$ & $51.5362^{* *}$ & $43.3282^{* *}$ & $55.3013^{* *}$ & $29.5023^{* *}$ & $41.8379 * *$ & $863.384^{* *}$ & $2451.5173^{* *}$ \\
\hline Error & 11 & 253.151 & 4.252 & 6.583 & 2.531 & 3.625 & 1.215 & 3.432 & 5.143 & 253.423 \\
\hline S.E. m \pm & 1.1340 & 1.135 & 1.236 & 1.635 & 0.932 & 1.502 & 0.223 & 51.231 & 1.137 \\
\hline C.V. (\%) & 3.5372 & 3.537 & 4.437 & 3.257 & 1.374 & 3.352 & 5.371 & 6.463 & 9.653 \\
\hline C.D. (5\%) & 2.2352 & 3.232 & 4.036 & 4.352 & 2.362 & 2.526 & 1.573 & 147.172 & 2.736 \\
\hline
\end{tabular}

Table 2: Variance analysis of 30 QPM hybrid crosses for eight characters.

Correlation coefficient of NCLB was observed between disease severity and AUDPC value in both season with range in minimum and maximum from 11.107 to $80.453(\mathrm{P}<0.0001)$. Disease severity as well as AUDPC value of the Rabi season 2015-16 were more highly significantly correlated to Kharif season in E2 environments as well as Rabi season in E2 environments. The correlation coefficient between days to sowing and AUDPC were non-significant when calculated across both season data of E1 environments.
NCLB reduced the yield of susceptible QPM hybrid maize but had little effect on partially resistant hybrids. This is yield effect of hybrid between 30 hybrid along with checks during Rabi season 2015-16. Therefore AUDPC showing independence variables due to different environments QPM cross growth patterns. QPM hybrid normally grow at temperature range from 1 to $40 \mathrm{oC}$, this range may affect the normal growth annually at considerable and varying circumstances. High temperature generally affects QPM

\begin{tabular}{|l|c|c|c|c|c|c|c|c|}
\hline Trait Parameter & $\begin{array}{c}\text { Days to 50 \% } \\
\text { Tasseling }\end{array}$ & $\begin{array}{c}\text { Days to 50\% } \\
\text { Silking }\end{array}$ & $\begin{array}{c}\text { Days to 75\% } \\
\text { Brown Husk }\end{array}$ & $\begin{array}{c}\text { Plant Height } \\
\text { (cm) }\end{array}$ & $\begin{array}{c}\text { Ear Height } \\
\text { (cm) }\end{array}$ & $\begin{array}{c}\text { Cob Length } \\
\text { (cm) }\end{array}$ & $\begin{array}{c}\text { 100 Grain } \\
\text { Weight }\end{array}$ & $\begin{array}{c}\text { G. Yield/ } \\
\text { Plant (gm) }\end{array}$ \\
\hline Range (M\&M) & 39.526 & 42.627 & 46.633 & 73.653 & 29.373 & 21.207 & 6.443 & 8.747 \\
\cline { 2 - 9 } & 46.537 & 54.353 & 62.200 & 126.625 & 71.450 & 41.223 & 21.477 & 22.473 \\
\hline Grand Mean & 52.050 & 55.960 & 88.270 & 106.840 & 47.430 & 12.590 & 16.890 & 35.500 \\
\hline S.E. m \pm & 1.169 & 1.440 & 1.668 & 0.965 & 1.002 & 0.628 & 1.233 & 1.548 \\
\hline Phenotypic Variance & 21.420 & 21.050 & 19.460 & 843.300 & 410.440 & 11.390 & 16.330 & 323.260 \\
\hline genotypic Variance & 17.330 & 14.830 & 16.130 & 847.510 & 397.430 & 10.210 & 11.770 & 326.070 \\
\hline PCV & 8.530 & 8.200 & 5.600 & 23.220 & 42.190 & 27.800 & 23.930 & 51.430 \\
\hline GCV & 8.000 & 6.810 & 4.530 & 25.240 & 40.030 & 25.370 & 20.310 & 50.870 \\
\hline $\mathrm{h}^{2}$ (Broad Sense) & 0.710 & 0.750 & 0.630 & 1.260 & 0.830 & 0.830 & 0.720 & 0.830 \\
\hline $\begin{array}{l}\text { Genetic Advancement at } \\
\text { K=2.06 }\end{array}$ & 5.710 & 6.640 & 6.520 & 69.870 & 43.910 & 6.270 & 6.200 & 35.790 \\
\hline $\begin{array}{l}\text { Gen. Adv as \% of Mean } \\
\text { 5\% }\end{array}$ & 9.820 & 13.900 & 14.610 & 53.640 & 73.240 & 49.460 & 35.520 & 106.630 \\
\hline
\end{tabular}

Table 3: Estimation of heritability and genetic advance as per cent of mean for eight characters in 30 QPM hybrid crosses.

hybrid parts (tassel, stamen and silk) due to abnormal biochemical reaction and death cell. Such type low temperature cause greater damage of maize crops than high temperature and damage cell membrane from excess photosynthesis due to formation intracellular space with in cell. The AUDPC of NCLB treatment showed of 30 crosses treatments along with 2 checks at C.D. (5\%). The critical value (CV) percentage was variable to each trait of QPM hybrids. The heritability and genetic advancement (at $\mathrm{K}=2.06)$ percentage showed at $5 \%$ mean, such types days to $50 \%$ tasseling (9.820), days to $50 \%$ silking (13.900), days to brown husk (14.610), plant height (53.640), ear height (73.24), cob length (49.46), 100 grain weight (35.52) and grain yield per plant (106.63) were showed.

NCLB and maize hybrid grain genotypes yields had significant relationships between two environment during Rabi season 2015-
16 and Kharif season 2016. In resistant QPM hybrid genotypes yield is increases but in susceptible genotypes critically loss of grain production and biological yield. The maize hybrid genotypes are moderately resistant towards NCLB inoculation exhibiting the effectiveness of selection for improving Northern Corn Leaf Blight resistance. Checks yield showed negative and inversely proportional relation with NCLB. As greater the disease incidence during Rabi season 2015-16 and diseased progressive curved area (AUDPC) lesser is the grain yield. Selected maize hybrid crosses between highly resistant and highly susceptible genotypes leads to the production of heterotic moderately resistant genotypes which are the key group for germplasm improvement with compare moderately and material resistant genetic and greater in number compare to susceptible and moderately susceptible. QPM resistant and moderately resistant group results in enhancement of yield during Kharif 
season in irrigated environment. Similar work previously published during [16]. It was reported grain yield variation from 23.9 to $40.4 \%$ with a mean of $33.3 \%$. Another finding also supported by [17], as yield depression was directly proportional to disease severity and grain losses range increased from $2.9-51.9 \%$ due to positive relation in Northern Corn leaf blight.

\section{Conclusions}

NCLB is a harmful disease in maize hybrid to which QPM crosses were slightly affected in rainfed environment due to cloudy and high moisture condition. Seasonal and regional occurrence of NCLB disease is great extent to determine temperature. The high temperature of Kharif season hybrid maize cross are minimize more pathogen activation but during Rabi season low temperature become active under favorable condition and cause disease in presence of sufficient moisture. The NCLB is more cause with presence of high moisture or high relative humidity in cloudy environment. NCLB disease is more appear in rain-fed environment during November to January month in the Northern part of India. Therefore, pretreatment is more requirements during Rabi season maize hybrid for removal to NCLB.

\section{Acknowledgements}

This work was support from CSIR New Delhi for Ph.D. work program. Special thanks are conveyed to Dr. Rajesh Singh (Professor), Department of Genetics and Plant Breeding, Institute of Agricultural Sciences, BHU, Varanasi for his constant encouragement and providing the resources to carry out the research work.

\section{Bibliography}

1. Cimmyt. "Maize disease. A guide for field identification". (4th Edit). Government of Pakistan. Minist. Food, Agric. Livestock, Econ. Wing. Islamabad, Pak (2004).

2. Faostat. "Statistical Database of the Food and Agriculture of the United Nations" (2008).

3. Krivanek AF., et al. "Breeding and disseminating quality protein maize (QPM) for Africa". African Journal of Biotechnology 6 (2007): 4 .

4. Sofi PA., et al. "Review article: Quality protein maize (QPM): Genetic manipulation for the nutritional fortification of maize". Journal of Plant Breeding and Crop Science 1 (2009): 244-253.

5. Scott Craig JS., et al. "The cyclic peptide synthetase catalyzing $\mathrm{HC}$ toxin production in the filamentous fungus Cochliobolus carbonum is encoded by a open reading frame". Journal of Biological Chemistry 267 (2009) 26044-26049.

6. Akuamoa-Boateng A. "Quality Protein Maize Infant Feeding Trials in Ghana". Ghana Health Service Report; Ghana Health Service: Ashanti, Ghana (2002).
7. Wende A., et al. "Preferences and constraints of maize farmers in the development and adoption of improved varieties in the mid-altitude, sub-humid agro-ecology of western Ethiopia". African journal of Agricultural Research 8 (2013): 1245-1254.

8. Leonard K., et al. "Proposed nomenclature for pathogenic races of Exserohilum turcicum on corn". Plant Disease (2013) 73:776-777.

9. Pant SK., et al. "Effect of turcicum leaf blight on photosynthesis in maize”. Indian Phytopathology 54 (2001) 251-252.

10. Costa RV and Cota LV. "Controle químico de doenças na cultura do milho: aspectos a serem considerados na tomada de decisão sobre aplicação". Sete Lagoas: Embrapa Milho e Sorgo (2009) 11.

11. Kimati H., et al. Manual de fitopatologia volume 2: Doenças das plantas cultivadas. 4. ed. São Paulo: Editora Agronômica CERES Ltda (2005) 494.

12. Kumar S., et al. "Evaluating interactive effect of initial screening hybrids in different environmental condition". International Journal of Agriculture Sciences 9:20 (2017)4204-4208.

13. Wheeler BEJ. "An Introduction to Plant Disease". Wiley, London (1969): 617-619.

14. Campbell CL and Madden. "Introduction to plant disease epidemiology”. John Wiley and Sons, New York (1990).

15. Jeger MJ. "Analysis of disease progress as a basis for evaluating disease management practices". Annual Review of Phytopathology 42 (2004) 61-82.

16. Harlapur SI. "Epidemiology and management of turcicum leaf blight of maize caused by Exserohilum turcicum (Pass.)”. Ph. D. Thesis, Univ. Agric. Sci., Dharwad, India (2005).

17. Patil VS. "Epidemiology and management of leaf blight of wheat caused by Exserohilum hawaiienesis (Bugnicourt)". Ph.D. thesis, Univ. Agric. Sci. Dharwad, India (2000).

\section{Assets from publication with us}

- Prompt Acknowledgement after receiving the article

- Thorough Double blinded peer review

- Rapid Publication

- Issue of Publication Certificate

- High visibility of your Published work

Website: www.actascientific.com/

Submit Article: www.actascientific.com/submission.php

Email us: editor@actascientific.com

Contact us: +919182824667 